\title{
Wykładnia operatywna sądu administracyjnego w roli gwaranta ochrony praw podatnika (wybrane uwagi)
}

Prawo podatkowe stanowi bardzo specyficzną gałąź prawa, jako że wyjątkowo specyficzny jest także główny przedmiot jego regulacji, a mianowicie całokształt stosunków pomiędzy związkiem publicznoprawnym a jednostką, których treścią jest obowiązek podatkowy. Funkcją regulacji podatkowoprawnej jest redystrybucja środków finansowych, tj. ich przepływ w formie podatków od jednostek do związku publicznoprawnego ${ }^{1}$. Ponieważ zaś podatek jest świadczeniem nie tylko nieodpłatnym, ale i przymusowym, to obciążenie nim jednostek z natury rzeczy często budzi w nich opór, nawet jeżeli czują się członkami społeczności zorganizowanej w związek publicznoprawny nakładający ów podatek².

W związku z powyższym metodą regulacji podatkowoprawnej stało się władztwo i podporządkowanie, skutkujące daleko posuniętą nierównorzędnością podstawowych podmiotów prawa podatkowego, tj. wierzyciela (podmiotu aktywnego) i dłużnika (podmiotu biernego) podatkowego. Taki rozkład sił w stosunku podatkowoprawnym rodzi określone niebezpieczeństwa dla podatnika. Wzrostowi tych niebezpieczeństw służy także naturalna dla rodzaju ludzkiego chęć posiadania i tendencja do wykorzystywania pozycji władzy do zaspokajania prywatnego interesu jej przedstawicieli, a także zła jakość przepisów prawa podatkowego. Niejasność i nieprecyzyjność prawa podatkowego powodują, że - jak pisał Adam Smith - ,każdego podatnika w mniejszym albo większym stopniu oddaje się w moc poborcy podatkowego, który może bądź dotkliwie obciążyć podatkiem niemiłego sobie podatnika, bądź też pod groźbą takiego obciążenia wymusić dla siebie jakiś podarunek albo dodatek. Nieokreślona wysokość opodatkowania wzbudza zuchwalstwo i sprzyja korupcji wśród grona ludzi z natury

* Dr Łukasz Karczyński - Katedra Prawa Finansowego, Wydział Prawa i Administracji, Uniwersytet Gdański.

${ }^{1}$ Szerzej: A. Gomułowicz, J. Małecki, Podatki i prawo podatkowe, Warszawa 2004, s. 142 148 wraz z przywołaną tam literaturą.

${ }^{2}$ Szerzej: A. Napiórkowska, Czy ktoś chroni podatnika?, [w:] P. Borszowski, A. Huchla, E. Rutkowska-Tomaszewska (red.), Podatnik versus organ podatkowy, Wrocław 2011, s. 144. 
niepopularnego nawet tam, gdzie nie są oni ani zuchwali, ani skorumpowani"’. Niezwykle trafne wydaje się więc stwierdzenie słynnego amerykańskiego adwokata Daniela Webstera (powtórzone następnie przez nie mniej słynnego sędziego Johna Marshalla), że nieograniczona władza nakładania podatków wiąże się niechybnie z władzą niszczenia ${ }^{4}$.

Wszystko to powoduje, że zarówno tworzenie, jak i stosowanie prawa podatkowego powinno cechować się wyjątkową ostrożnością, a nawet - można by rzec - delikatnością względem jednostki narażonej na nadużycia władzy podatkowej. Ochronie interesów podatnika służą przeto rozmaite instrumenty prawne: wynikające z Konstytucji ogólne zasady materialnego prawa podatkowego (w szczególności zasada nullum tributum sine lege), system urzędowych interpretacji prawa podatkowego czy gwarancje procesowe ${ }^{5}$. Bezpieczeństwo prawne podatnika wymaga jednak nie tylko dobrego prawa, ale i odpowiedniego jego stosowania ${ }^{6}$.

Biorąc pod uwagę, że - w ujęciu psychologicznym - dysponowanie władzą może zdegenerować praktycznie każdego piastuna organu administracji publicznej, koniecznym instrumentem zapobiegania nadużyciom jest kontrola zewnętrzna. Jak pisał Czesław Znamierowski, „,w dobrze urządzonym państwie całą strukturę ciała rządzącego przenikać powinna zasada nieufności, a na niej powinien być oparty szeroko rozgałęziony system urządzeń kontrolnych"7. We współczesnych systemach prawnych istnieje wiele rodzajów kontroli administracji publicznej ${ }^{8}$. Jednym z nich jest kontrola sądowa, a więc kontrola o charakterze zewnętrznym, niezależnym od aparatu administracyjnego.

Sąd administracyjny stanowi niezwykle istotny element państwa prawa, pozwalający zrównoważyć pozycje stron stosunku podatkowoprawnego. Spór pomiędzy podatnikiem a organem podatkowym charakteryzuje się bowiem tym, że - biorąc pod uwagę kryteria merytoryczne, a nie tylko formalne - organ na etapie postępowania podatkowego występuje w nim w podwójnej roli: strony sporu oraz sędziego. Dwuinstancyjny tok postępowania nie daje przy tym podatnikowi

${ }^{3}$ A. Smith, Badania nad natura i przyczynami bogactwa narodów, t. 2, Warszawa 2007, s. 501.

${ }^{4}$ Stwierdzenia te pochodzą z akt sprawy McCulloch $v s$. Maryland z $1819 \mathrm{r}$.

${ }^{5}$ Por. A. Kowalska, M. Kowalska, Organ podatkowy - przeciwnik w sporze czy podmiot chroniacy interes podatnika?, [w:] P. Borszowski, A. Huchla, E. Rutkowska-Tomaszewska (red.), op. cit., s. 96-97; R. Mastalski, Orzecznictwo podatkowe Trybunatu Konstytucyjnego a polski system podatkowy, „Państwo i Prawo” 1993, nr 4, s. 7; Ł. Karczyński, Podstawowe zasady materialnego prawa podatkowego, „Przegląd Naukowy Wyższej Szkoły Społeczno-Ekonomicznej” 2007, nr 6, s. 185-186.

${ }^{6}$ Por. R. Mastalski, Podstawowe problemy orzecznictwa podatkowego, [w:] J. Góral, R. Hauser, J. Trzciński (red.), Sądownictwo administracyjne gwarantem wolności i praw obywatelskich 1980-2005, Warszawa 2005, s. 318.

${ }^{7}$ C. Znamierowski, Elementarne wiadomości o państwie, [w:] idem, Elita, ustrój, demokracja. Pisma wybrane, Warszawa 2001, s. 138.

8 J. Jagielski, Kontrola administracji publicznej, Warszawa 2007, s. 41 i n. 
należytej ochrony, skoro zarówno naczelnicy urzędów skarbowych (celnych), jak i dyrektorzy izb skarbowych (celnych) usytuowani są w tym samym pionie administracyjnym i podlegają tym samym zwierzchnikom, przez których mogą być poddawani wpływom w rozmaitej formie ${ }^{9}$. Przeniesienie tego sporu przed sąd administracyjny eliminuje nierównorzędność podmiotów stosunku podatkowoprawnego. Sąd ten rozstrzyga bowiem spór między jednostką a organem z pozycji niezależnej od każdej ze stron. W ten sposób może on odpowiednio realizować potrzebę ochrony praw podmiotowych jednostki w sferze prawa publicznego ${ }^{10}$.

W państwie demokratycznym nadużycia pozycji władzy ze strony organów podatkowych mogą pojawiać się w szczególności tam, gdzie orzekanie niekorzystne dla podatnika nie jest wyraźnym działaniem contra legem. Spór pomiędzy podatnikiem a organem podatkowym dużo częściej niż w innych gałęziach prawa przybiera charakter sporu o sposób interpretacji przepisów - jest to spór o kształt prawa, a nie faktów. Zjawisko to jest efektem wspomnianej już złej jakości przepisów prawa podatkowego. Przepisy te tworzone są często w pośpiechu i chaosie. Celem nazbyt częstych zmian staje się realizacja bieżących interesów fiskalnych państwa czy - rzadziej - samorządu. W takich warunkach starania o należytą technikę legislacyjną schodzą na dalszy plan. Brakuje dbałości i konsekwentnych działań, zmierzających do utworzenia możliwie prostego i spójnego systemu podatkowoprawnego ${ }^{11}$.

Niejasność prawa powoduje, że organ podatkowy nie musi jawnie działać niezgodnie z przepisami prawa podatkowego, by krzywdzić podatnika. Wystarczy, że działa on w ramach prawa - pod warunkiem, że prawo to jest na tyle niejasne, że stwarza pole do rozbieżnych interpretacji. Organ nie naraża się wówczas na zarzut wykładni prawotwórczej, skoro działa cały czas w ,pasie nieostrości” danego przepisu prawnego ${ }^{12}$. Wybór interpretacji niekorzystnej dla podatników staje się wówczas wygodnym sposobem zwiększania wpływów budżetowych.

Do sądów administracyjnych trafiają najczęściej właśnie tego typu spory. Jednak wykładnia sądowa bardzo często okazuje się profiskalna. Pojawić się może pytanie o powody takiej sytuacji. Ustalone w doktrynie ${ }^{13}$ metody wykładni prawa podatkowego nie są wprawdzie szczególnie proste, są jednak stosunkowo ścisłe i przypominają swoisty algorytm dążenia do celu, jakim jest orzeczenie

9 Nie dotyczy to postępowania odwoławczego od decyzji organów samorządowych, gdzie organem prowadzącym postępowanie jest niezależne od nich samorządowe kolegium odwoławcze.

10 J. Trzciński, Sądownictwo administracyjne jako gwarant ochrony wolności i praw jednostki [w:] A. Szmyt (red.), Trzecia władza. Sądy i trybunaty w Polsce, Gdańsk 2008, s. 129.

11 Por. R. Mastalski, Podstawowe problemy orzecznictwa podatkowego, [w:] J. Góral, R. Hauser, J. Trzciński (red.), op. cit., s. 319.

12 Por. M. Zieliński, Jednolitość wykładni prawa [w:] S. Waltoś (red.), Jednolitość orzecznictwa w sprawach karnych, Kraków 1998, s. 60.

13 Zob. w szczególności: B. Brzeziński, Podstawy wykładni prawa podatkowego, Gdańsk 2008. 
zgodne z przepisami podatkowymi, stosowanymi jednak z uwzględnieniem ratio legis regulacji i zasad konstytucyjnych: wyłączności ustawy w regulacji podatkowoprawnej, zasady zaufania do państwa i prawa (spajającej szereg innych zasad, w tym zasady lex retro non agit, lex benignior, zasad jawności, pewności i określoności prawa czy też ochrony praw słusznie nabytych i interesów w toku), zasady sprawiedliwości podatkowej (równości i powszechności opodatkowania), zasady rozstrzygania wątpliwości na korzyść podatnika (in dubio pro tributario), zasady ograniczonego (tylko na korzyść podatnika) stosowania analogii i wykładni rozszerzającej w prawie podatkowym, zasady respektowania terminologii przejętej $z$ innych gałęzi prawa ${ }^{14}$. W tym sensie wykładnia prawa podatkowego ma charakter w znacznej mierze ,techniczny”, odhumanizowany. Ta dehumanizacja dotyczy jednak tylko środka wykorzystywanego w procesie stosowania prawa, a nie jego celu. Celem jest bowiem zagwarantowanie poszanowania przez związek publicznoprawny godności ludzkiej, wolności i wszelkich innych konstytucyjnych praw podmiotowych jednostki, a więc postulat stawiający tę właśnie jednostkę, jako słabszą stronę sporu, w centrum uwagi.

Niewątpliwie zatem można wskazać spójne i przejrzyste zasady wykładania normy z przepisu prawa podatkowego, prowadzące do konsekwentnie analogicznych rezultatów subsumpcji w podobnych stanach faktycznych. Mimo to w orzecznictwie sądowym nierzadko zdarzają się wypadki naruszenia tychże zasad, nawet jeżeli nie występują one we wzajemnym konflikcie. Należy jednak zauważyć, że w tym wypadku, gdy ogólne reguły wykładni nie wystarczają do jednoznacznego ustalenia treści normy prawnej, pozostaje dyrektywa wykładni drugiego stopnia w postaci zasady in dubio pro tributario. Gdy zaś rezultat wykładni jest niewątpliwy, ale narusza podstawowe zasady konstytucyjnego porządku prawnego, jako ostateczny środek należy wykorzystać regułę odstąpienia od językowego sensu wykładni na podstawie argumentum ad absurdum. Te dwie ostatnie reguły sądy administracyjne stosują jednak niezwykle rzadko.

Ze względu na swoją wagę na odrębne omówienie zasługuje zasada in $d u$ bio pro tributario. Dubium (wątpliwość) pojawia się wówczas, gdy powstaje wyjątkowo trudno rozwiązywalny konflikt pomiędzy różnymi sposobami wykładni lub gdy sama reguła wykładni ma charakter nieostry (np. ustalenie granicy absurdu uzasadniającego odstąpienie od językowego rezultatu wykładni). Dubium jednak nie należy traktować jako pola do wykazania sędziowskiej niezależności i niezawisłości (i orzeczenia wedle osobistego pojęcia sprawiedliwości), lecz do zastosowania omawianej metazasady interpretacyjnej (zasady drugiego stopnia, dyrektywy wyboru) i w konsekwencji orzeczenia pro tributario. Nadal powinien zatem przeważać „,techniczny” sposób wykładni, a nie ,zasady słuszności”, właściwe bardziej dla prawa prywatnego (w którym jednak co do zasady spór toczy się między stronami o równej pozycji).

${ }^{14}$ Szerzej Ł. Karczyński, op. cit., s. 185 i n. 
Zasada rozstrzygania wątpliwości na korzyść podatnika nie jest jednak często stosowana $\mathrm{w}$ orzecznictwie sądów administracyjnych. Z analizy wyroków NSA zapadłych w pierwszym kwartale 2012 r. wynika, że NSA w tym okresie nie oparł na niej - przynajmniej wyraźnie - ani jednego wyroku (choćby w części czy pomocniczo). Albo więc sądy nie chcą jej stosować, albo nie miewają wątpliwości co do wyniku swojej wykładni. Skąd bierze się ta swoista niechęć orzecznicza? Być może ma ona podłoże psychologiczne - uznanie zaistnienia wątpliwości może wydawać się równoznaczne z przyznaniem się do niewiedzy. Jednak wystąpienie wątpliwości nie świadczy wcale o niewiedzy. Dubium pojawia się pomimo należytej wiedzy. Co więcej, prawidłowe stwierdzenie zaistnienia dubium wymaga szczególnie wysokich kompetencji w dziedzinie interpretacji prawa. Występowanie uzasadnionych wątpliwości jest więc sytuacją normalną, choć nieczęstą. Z pewnością jednak nie jest tak, że nie występuje ona wcale - jak mogłoby wynikać z najnowszego orzecznictwa NSA. Sąd nie musi być wszechwiedzący, powinien jednak wiedzieć, jak stosować zasady wykładni.

Powyższe uwagi prowadzą do konstatacji, że z uwagi na ochronę podatnika sąd może dopuścić zarówno stosowanie niejasnego przepisu w sposób nieracjonalny (z punktu widzenia fiskusa), jak i niestosowanie wyraźnego i jasnego przepisu niekorzystnego dla podatnika (jeżeli narusza on wymienione wcześniej zasady konstytucyjne lub jest oczywiście absurdalny). Czy jednak sąd nie powinien chronić także interesów fiskalnych państwa? Na to pytanie należy odpowiedzieć negatywnie. Podstawowym zadaniem sądownictwa administracyjnego jest bowiem ochrona obywatela przed nadużyciami władzy, a nie ochrona państwa przed jego własnymi błędami. Na przykład, gdyby w przepisach istniała niekorzystna dla państwa luka prawna, to sąd nie powinien luki tej zapełniać szeroko pojętą wykładnią o charakterze prawotwórczym, lecz raczej pamiętać o zasadzie wyłączności ustawy w kształtowaniu obowiązku podatkowego. $Z$ kolei w przypadku wielości rezultatów wykładni językowej sąd powinien stosować wykładnię celowościową wyłącznie na korzyść podatnika, a odwrotnie - z zachowaniem wymaganej ostrożności - tylko w przypadkach rażąco naruszających inne podstawowe zasady prawa podatkowego ${ }^{15}$ lub w sytuacjach ewidentnie absurdalnych ${ }^{16}$. Sąd administracyjny powinien więc orzekać zgodnie z dyspozycją zasad wynikających z konstytucyjnego zakwalifikowania Rzeczypospolitej Polskiej do grona demokratycznych państw prawnych, ucząc tym samym ustawodawcę, że stanowienie złego prawa obraca się przeciw niemu samemu. Państwo dysponuje wszak aparatem władzy, umożliwiającym mu względnie szybką naprawę błędów legislacyjnych. Jeżeli z niego nie korzysta, to nie powinno odbywać się to kosztem indywidualnego podatnika. W orzecznictwie i doktrynie wielokrotnie podkreślano, że państwo nie powinno czerpać korzyści z własnych błędów legisla-

${ }^{15}$ W szczególności zasadę równości opodatkowania.

${ }^{16}$ Na przykład w zakresie naruszeń podstawowych zasad konstrukcji danego podatku (np. zasady jednokrotności odliczenia kosztu uzyskania przychodu w podatkach dochodowych). 
cyjnych, a podatnikowi można zarzucić niedopełnienie obowiązku tylko wtedy, gdy jego treść i zakres są w pełni zrozumiałe ${ }^{17}$. Sąd administracyjny nie powinien zatem wyręczać prawodawcy w jego konstytucyjnych zadaniach, a raczej skupić się na własnej podstawowej funkcji: ochronie jednostki przed nadużyciami władzy - i to nie tylko wykonawczej, lecz także ustawodawczej. Poprawianie prawa podatkowego, jeżeli ma rozszerzać zakres opodatkowania, jest bowiem zadaniem państwa, a nie sądów. Sąd zaś powinien raczej być swoistym wychowawcą ustawodawcy, stawiającym mu ograniczenia i nie przymykającym oka na błędy. Obecnie sądy administracyjne nazbyt często okazują się nadopiekuńcze wobec państwa; tymczasem można przypuszczać, że z czasem zmiana „metody wychowawczej" przyczyniłaby się do poprawy jakości polskiego prawa podatkowego. Sąd nie powinien więc zastanawiać się, który rezultat wykładni jest jego zdaniem słuszny i sprawiedliwy (jak gdyby przepisów w ogóle nie było i tworzył on normy od podstaw), tworząc prawo jakby w pustce legislacyjnej, dopasowując uzasadnienie do z góry założonego rezultatu, lecz raczej oprzeć się na ścisłych regułach wykładni, w szczególności: interpretowaniu zwrotów przejętych z innych gałęzi prawa zgodnie z ich pierwotnym znaczeniem (chyba że kontekst wskazuje na co innego), dokładnej analizie ratio legis, stosowaniu analogii na korzyść podatnika (w przypadku luk prawnych) czy zasadzie in dubio pro tributario.

Istotne jest ponadto, że pomijanie przez sądy administracyjne ustalonych w doktrynie reguł wykładni prawa podatkowego prowadzi do pojawiania się rozbieżności interpretacyjnych. Niektóre składy sędziowskie korzystają z dorobku doktryny i orzecznictwa w zakresie metod interpretacji, a inne nie, zdając się na czynniki odmienne. Częste są, niestety, długotrwałe rozbieżności interpretacyjne - sytuacje, w których nawet przez kilka lat „obowiązują” równolegle dwie odmienne linie orzecznicze. Okoliczności te budzą uzasadnione obawy, gdyż nie sprzyjają budowaniu w podatnikach postawy zaufania do instytucji państwowych. Dotyczy to w szczególności rozbieżności interpretacyjnych w obrębie orzeczeń wydawanych przez NSA. Niejednokrotnie zdarza się, że NSA przez dłuższy czas rozstrzyga równolegle analogiczne sprawy na skrajnie odmienne sposoby. Taka sytuacja powoduje, że podatnik znajdujący się w danej sytuacji nie ma praktycznie żadnej pewności co do tego, jak zostanie rozstrzygnięty jego ewentualny spór, a więc nie może racjonalnie planować swoich interesów gospodarczych. Tymczasem, jak już zasygnalizowano, pewność prawa jest jednym z najistotniejszych postulatów w zakresie regulacji opodatkowania. W ogóle zresztą uznaje się ją za jeden $\mathrm{z}$ najbardziej istotnych czynników funkcjonowania prawa w społeczeństwie, co należy odnosić zwłaszcza do prawa podatkowego jako gałęzi o relatywnie

17 Wyrok NSA z 18 stycznia 1988 r. (sygn. akt III SA 702/87, „Orzecznictwo NSA” 1987, nr 2) wraz z aprobującą glosą Z. Kmieciaka (wyrok i glosa w: „Orzecznictwo Sądów Polskich” 1990, nr 5-6); P. Witkowski, Zasady ogólne postępowania administracyjnego w prawie podatkowym (1), „Przegląd Podatkowy” 1997, nr 7, s. 27; J. Małecki, Przeksztatcenia orzecznictwa sądów administracyjnych w sprawach podatkowych (w latach 1981-2005), „Zeszyty Naukowe Sądownictwa Administracyjnego" 2010, nr 5-6, s. 307. 
wysokim stopniu represyjności. Wyrazem pewności prawa jest możliwość jego jednolitego rozumienia i stosowania, co na gruncie wykładni oznacza możliwość przewidywania, jakie rozstrzygnięcia wydadzą podmioty stosujące prawo ${ }^{18}$. W obecnej sytuacji sądownictwa administracyjnego nazbyt często możliwości takiej brakuje. Co można zrobić - oprócz zwracania uwagi na ten problem - by go rozwiązać?

W doktrynie ${ }^{19}$ wyróżnia się cztery instytucje ujednolicające orzecznictwo sądowe:

1) kontrolę orzeczeń wskutek zaskarżenia;

2) mechanizmy ujednolicające orzecznictwo sądów najwyższych (w przypadku sądownictwa administracyjnego - uchwały NSA);

3) kierowanie się dotychczasowym orzecznictwem (precedensy faktyczne);

4) doktrynę i edukację prawniczą.

Jak wskazuje obecna praktyka orzecznicza WSA i NSA, powyższe instytucje okazują się niewystarczające. Pierwsza z nich z oczywistych względów nie dotyczy orzeczeń NSA, podczas gdy to właśnie rozbieżności w obrębie tego sądu stanowią główny problem podatników (słuszny jest zatem postulat dotyczący wprowadzenia mechanizmu usuwania z obrotu prawnego wyroków NSA oczywiście błędnych ${ }^{20}$ ). Druga jest mechanizmem skutecznym, ale nie pełni funkcji prewencyjnej ani nawet naprawczej, gdyż działa z opóźnieniem i wyłącznie na przyszłość. Trzecia zawodzi w przypadku pojawienia się jednego czy kilku orzeczeń odbiegających od pozostałych, prowadząc niekiedy do wykształcenia odrębnej linii orzeczniczej - nie jest zresztą w żaden sposób unormowana. Czwarta ma ograniczoną siłę oddziaływania ze względu na całkowity brak normatywności.

Warto tu wspomnieć o słusznym postulacie wprowadzenia reguł wykładni prawa podatkowego o charakterze albo normatywnym, albo orzeczniczym, oddziałującym wyłącznie siłą autorytetu, podobnie jak w przypadku instrumentu czwartego $^{21}$. Regulacja normatywna nie naruszałaby niezależności czy niezawisłości sędziów, ponieważ zostałaby wprowadzona ustawowo, z zachowaniem wszelkich wymogów konstytucyjnych (zasada niezawisłości sędziowskiej już obecnie nie oznacza zresztą całkowitego nieskrępowania jakimikolwiek zasadami metodologicznymi w zakresie wykładni ${ }^{22}$ ). Gdyby zaś wyraźną regulację metod wykładni pozostawić orzecznictwu, to i w tym przypadku nie powinno

${ }_{18}$ Por. R. Mastalski, [w:] B. Adamiak, J. Borkowski, R. Mastalski, J. Zubrzycki, Ordynacja podatkowa. Komentarz, Wrocław 2008, s. 136.

${ }^{19}$ L. Leszczyński, Legitymizacja instytucji ujednolicajacych orzecznictwo sądowe, [w:] S. Waltoś (red.), op. cit., s. 34.

${ }^{20}$ B. Brzeziński, Glosa do wyroku NSA z 2 lutego 2011 r. (sygn. akt II FSK 1653/09), „Przegląd Orzecznictwa Podatkowego" 2011, nr 4, s. 327 i 329.

${ }^{21}$ Por. M. Zieliński, op. cit., s. 67; B. Brzeziński, Kilka uwag o przepisach normujacych wykładnię prawa podatkowego, [w:] A. Choduń, S. Czepita (red.), W poszukiwaniu dobra wspólnego. Księga jubileuszowa Profesora Macieja Zielińskiego, Szczecin 2010, s. 343-346.

${ }^{22}$ M. Zieliński, op. cit., s. 65. 
być wątpliwości, że siła jej oddziaływania byłaby o wiele większa w porównaniu z siłą doktryny (która do chwili obecnej wypracowała wszak względnie jednolite zasady wykładni prawa, w tym podatkowego, które nie zawsze są przez sądy stosowane), byłaby to bowiem siła pochodząca z samego aparatu orzeczniczego, a nie narzucona $\mathrm{z}$ zewnątrz.

Przedstawione powyżej krytyczne uwagi co do działalności sądów administracyjnych nie umniejszają w żaden sposób ogromnej roli, jaką zwłaszcza w latach 80. i 90. odegrał NSA w budowie państwa prawa, dbającego o ochronę interesu jednostki w starciu z interesem publicznym ${ }^{23}$ - i którą, wraz z sądami wojewódzkimi, niewątpliwie odgrywa nadal, choć zapotrzebowanie na taką działalność na szczęście znacząco się już zmniejszyło. Obecnie celowe jest jednak zwrócenie uwagi na pewne niedomagania w funkcjonowaniu systemu sądownictwa administracyjnego. Warto bowiem, by w przyszłości można było zapewnić jeszcze lepszą ochronę praw podatnika przez sądy administracyjne. Gwarancje odpowiedniego traktowania jednostki w sporze $\mathrm{z}$ administracją podatkową są niezwykle ważne, skoro to m.in. dzięki nim jednostka może przyjąć nastawienie, że jej własne państwo traktuje ją jako pełnoprawnego członka społeczności i że uiszczenie podatku pozwala realizować dobro wspólne, z korzyścią także dla tej jednostki. Aby podatnicy mogli w jak największym stopniu identyfikować się z instytucją społeczną pobierającą podatki, a jej cele traktować jako zbliżone do własnych, pobór podatków powinien w jak najmniejszym stopniu przypominać grabież (w swej istocie pobór podatków stanowi w pewnym sensie prawnie usankcjonowany zabór mienia, przy czym cel tego zaboru w świadomości podatnika schodzi często na dalszy plan), a w jak największym - dobrowolną zbiórkę na użyteczny cel. Podatnik, który dostrzega sens w zapłacie podatku i sprawiedliwość w zasadach jego poboru, będzie bardziej skłonny prawidłowo wykonywać swoje zobowiązania ${ }^{24}$. Słuszne i prawidłowo stosowane prawo podatkowe jest więc istotnym elementem kształtowania wśród społeczeństwa zaufania do państwa i prawa oraz ogólnie postawy legalistycznej czy identyfikacji podatnika z własnym państwem, co dodatkowo sprzyja budowie systemu prawa responsywnego, nastawionego na potrzeby społeczeństwa, a nie władzy ${ }^{25}$. Im zaś sprawniejsze sądownictwo administracyjne, tym szybciej państwo może zmierzać ku temu celowi.

${ }^{23}$ Szerzej: J. Małecki, Przekształcenia orzecznictwa sąów administracyjnych ..., s. 309-310; J. Małecki, O ciagłości konstrukcji podatkowych w świetle orzecznictwa Najwyższego Trybunatu Administracyjnego i Naczelnego Sądu Administracyjnego, [w:] J. Góral, R. Hauser, J. Trzciński (red.), op. cit., s. 302-304.

${ }^{24}$ Por. w aspekcie moralności w opodatkowaniu: A. Gomułowicz, Etyka a opodatkowanie, [w:] J. Góral, R. Hauser, J. Trzciński (red.), op. cit., s. 180-181.

${ }_{25}$ Por. B. Brzeziński, Relacje między administracja podatkowa a podatnikami - od konfrontacji do wspótpracy, [w:] P. Borszowski, A. Huchla, E. Rutkowska-Tomaszewska (red.), op. cit., s. 37,41 . 